\title{
STUDI PENCAPAIAN KOMPETENSI MEMBUBUT RATA DAN BERTINGKAT UNTUK MAHASISWA JPTM UPI YANG BERASAL DARI SMA DAN SMK
}

\author{
Wanday M. P. Iskandar ${ }^{1}$, Uli Karo Karo ${ }^{2}$, Asep H. Sasmita ${ }^{3}$ \\ Departemen Pendidikan Teknik Mesin, FPTK UPI \\ Jl. Dr. Setiabudi No. 207 Bandung 40154 \\ wanday182@Gmail.com
}

\begin{abstract}
ABSTRAK
Penelitian ini bertujuan untuk mengetahui perbedaan pencapaian kompetensi membubut rata dan bertingkat untuk mahasiswa yang berlatar belakang pendidikan dari SMA dan dari SMK pada mata kuliah teknik pemesinan. Metode yang digunakan pada penelitian ini yaitu metode komparatif dengan pendekatan kuantitatif. Pengumpulan data pada penelitian ini dilakukan dengan test performance dimana mahasiswa melakukan pekerjaan dengan mesin bubut menggunakan panduan berdasarkan job sheet. Hasil penelitian menunjukkan bahwa rata-rata pencapaian kompetensi membubut rata dan bertingkat mahasiswa yang berlatar belakang pendidikan dari SMA dan dari SMK tidak ada perbedaan yang signifikan.
\end{abstract}

Kata kunci: kompetensi, bubut rata, tes kinerja

\section{PENDAHULUAN}

Perkembangan dunia pendidikan sejalan dengan perkembangan ilmu pengetahuan dan teknologi yang demikian pesat menuntut Sumber Daya Manusia (SDM) yang berkualitas tinggi dalam berbagai bidang, termasuk dalam Bidang Teknologi dan Kejuruan. Sejalan dengan perkembangan IPTEK yang pesat tersebut, mempersiapkan SDM untuk masa kini dan mengantisipasi untuk masa depan merupakan hal yang tidak bisa ditawar-tawar lagi. Oleh karena itu, SDM yang mempunyai kualifikasi dalam pengembangan, pengelolaan dan pelaksanaan program-program Pendidikan Kejuruan/Latihan khususnya dalam bidang Teknologi dan Kejuruan menjadi penting.

Pendidikan sebagai salah satu subsistem dalam pembangunan nasional memegang peranan yang cukup besar dalam upaya mewujudkan tujuan pembangunan nasional. Pendidikan nasional sebagi suatu proses dalam upaya pembentukan manusia seutuhnya dan kesejahteraan seluruh masyarakat, seperti yang diamanatkan dalam Undang-Undang Republik Indonesia No. 20 Tahun 2003 Bab 2 Pasal 3 tentang fungsi dan tujuan pendidikan nasional, yaitu: pendidikan

\footnotetext{
${ }^{1}$ Mahasiswa Departemen Pendidikan Teknik Mesin FPTK UPI

${ }^{2}$ Dosen Departemen Pendidikan Teknik Mesin FPTK UPI

${ }^{3}$ Dosen Departemen Pendidikan Teknik Mesin FPTK UPI
} 
nasional berfungsi mengembangkan kemampuan dan membentuk watak serta peradaban bangsa yang bermartabat dalam rangka mencerdaskan kehidupan bermartabat dalam rangka mencerdaskan kehidupan bangsa, bertujuan untuk berkembangnya potensi peserta didik agar menjadi manusia yang beriman dan bertakwa kepada Tuhan Yang Maha Esa, berakhlak mulia, sehat, berilmu, cakap, kreatif, mandiri dan menjadi warga negara yang demokratis serta bertanggung jawab.

Pendidikan tinggi merupakan pendidikan lanjutan dari pendidikan menengah, sesuai dengan yang tercantum pada Kepmendiknas. No.232/U/2000 Pasal 1 ayat 1, yaitu: pendidikan tinggi adalah kelanjutan pendidikan menengah yang diselenggarakan untuk menyiapkan peserta didik untuk menjadi anggota masyarakat yang memiliki kemampuan akademik dan/atau profesional yang dapat menerapkan, mengembangkan dan menciptakan ilmu pengetahuan, teknologi dan kesenian. Selain dari itu, di ayat 2: perguruan tinggi adalah satuan pendidikan yang menyelenggarakan pendidikan tinggi yang dapat berbentuk Akademik, Politeknik, Sekolah Tinggi, Institut atau Universitas. Jurusan Pendidikan Teknik Mesin (JPTM) Fakultas Pendidikan Teknologi dan Kejuruan (FPTK) Universitas Pendidikan Indonesia (UPI), memiliki mahasiswa yang berasal dari SMA maupun SMK. Latar belakang pendidikan mahasiswa tersebut tentunya memiliki pengalaman belajar yang berbeda-beda ketika mengikuti perkuliahan.

JPTM FPTK UPI memiliki struktur kurikulum yang terdiri dari berbagai mata kuliah, salah satunya mata kuliah Teknik Pemesinan (PP253). Pada mata kuliah Teknik Pemesinan ini dirancang dengan pendekatan kompetensi dan menggabungkan strategi klasikal, individu, dan kelompok (Slameto, 2003). Untuk mendukung pelaksanaan perkuliahan digunakan perlengkapan seperti job sheet, mesin bubut, mesin frais, mesin skraf dan perlengkapannya, alat ukur dan alat keselamatan kerja. Untuk mengukur tingkat penguasaan mahasiswa, dilakukan melalui terhadap penguasaan teori, juga dilakukan evaluasi terhadap kemampuan praktek dengan menggunakan evaluasi kinerja. Selain itu, digunakan evaluasi terhadap tugas (laporan hasil praktiik) dan evaluasi melalui UTS dan UAS.

Mata kuliah ini harus diikuti mahasiswa Jurusan Pendidikan Teknik Mesin dari awal sampai akhir perkuliahan tanpa dibedakan asal sekolahnya, baik dari SMA maupun dari SMK. Harapan JPTM FPTK UPI terhadap mahasiswa tersebut memiliki peluang yang sama dalam mempraktekkan hasil belajar yang baik pada akhir perkuliahan. Meskipun demikian, berdasarkan asal sekolahnya, mahasiswa yang berasal dari SMK memiliki peluang lebih besar mendapatkan 
prestasi yang lebih baik daripada mahasiswa asal SMA, oleh karena mahasiswa asal SMK lebih terbiasa dengan suasana teori dan praktek kejuruan.

Secara umum tujuan penelitian ini adalah untuk mengetahui sejauh manaperbedaan kemampuan praktek mahasiswa yang berasal dari SMA dan SMK padamata kuliah Teknik Pemesinan JPTM UPI. Selain dari itu penelitian iniberdasarkan pada rumusan yang telah di kemukakan di atas, penelitianini mempunyai tujuan khusus sebagai berikut: mengetahui pencapaian kompetensi membubut rata dan bertingkat, mengetahui pencapaian kompetensi membubut rata dan bertingkat dan mengetahui perbedaan pencapaian kompetensi membubut rata dan bertingkat mahasiswa yang berasal dari SMA dengan mahasiswa yang berasal dari SMK pada mata kuliah Teknik Pemesinan.

Standar kompetensi pendidikan diperlukan agar tidak terjadi penyimpangan, dan kesalahan dalam manafsirkan dan mengimplementasikan kurikulum. Penetapan standar kompetensi yang harus dicapai oleh setiap peserta didik dapat mengurangi penyimpangan dan mengeleminasi salah tafsir dalam implementasi kurikulum. Dalam hal ini, standar kompetensi untuk peserta didik tidak perlu sama untuk setiap daerah tetapi disesuaikan dengan kebutuhan dan kondisi serta berbagai aspek pendukungnya pada masing-masing setiap daerah. Pada prinsipnya penetapan kompetensi tamatan SMK mengacu kepada standar kompetensi yang di tuntut dunia kerja (baik dunia usaha maupun dunia industri) sesuai dengan bidangnya masing-masing. Penetapan program pembelajaran harus ditempuh oleh peserta diklat (siswa), ditetapkan berdasarkan kompetensi tersebut.

Mengenai pembahasan kompetensi dalam pendidikan kejuruan ini, maka tidak terlepas dari pengertian dasar kompetensi. Beberapa ahli mendefinisikan kompetensi dengan berbagai macam ilustrasi atau penjelasan yang memiliki karakteristik masing-masing. Kompetensi adalah kemampuan dasar yang dapat dilakukan oleh para siswa pada tahap pengetahuan, keterampilan, dan sikap (Yamin, 2005). Kemampuan dasar inilah yang dijadikan landasan dalam melakukan proses pembelajaran dan penilaian siswa.

Kompetensi atau pendidikan berbasis kompetensi dalam makna yang lebih luas tidak hanya terkait dalam dunia kerja semata, tetapi mencakup semua aspek dalam diri seseorang yang diterapkan sebagai suatu karakter yang mantap dalam menjalani kehidupan sehari-hari. Kompetensi dalam makna yang lebih luas mencakup semua kecakapan, kebiasaan, keterampilan yang diperlukan seseorang dalam kehidupannya, baik sebagai pribadi, warga masyarakat, siswa 
dan karyawan (termasuk di dalamnya pimpinan) (Sukmadinata, 2004). Secara umum kompetensi mempunyai makna yang hampir sama dengan keterampilan hidup atau life skill, secara terperinci yaitu meliputi kecakapan-kecakapan, keterampilan untuk menyatakan, memelihara, menjaga, dan mengembangkan diri. Namun kecakapan-kecakapan tersebut tidak hanya berkenaan dengan aspek fisik-biologis, tetapi juga meliputi aspek-aspek intelektual, sosial, dan afektif (perasaan, sikap, nilai).

Kompetensi merupakan perpaduan dari pengetahuan, keterampilan, nilai-nilai dasar dan sikap yang direfleksikan dalam kebiasaan berfikir dan bertindak. Kebiasaan berfikir dan bertindak secara konsisten dan terus menerus memungkinkan seseorang menjadi kompeten, dalam arti memiliki pengetahuan, keterampilan dan nilai-nilai dasar untuk melakukan sesuatu. Kompetensi adalah penguasaan terhadap suatu tugas, keterampilan, sikap, dan apresiasi yang diperlukan untuk menunjang keberhasilan (Mulyasa, 2002). Hal tersebut menunjukkan bahwa kompetensi mencakup tugas, keterampilan, sikap dan apresiasi yang harus dimiliki peserta didik untuk dapat melaksanakan tugas-tugas pembelajaran sesuai dengan jenis pekerjaan tertentu. Dengan demikian terdapat hubungan (link) antara tugas-tugas yang dipelajari peserta didik di sekolah dengan kemampuan yang diperlukan oleh dunia kerja.

Bertitik tolak dari pokok-pokok pikiran tentang Teknik Pemesinan, bahwa sebagai kemampuan penguasaan bidang studi, kemampuan berkarya secara mandiri, penerapan bidang studi kedalam praktek. Evaluasi (penilaian) hasil belajar peserta didik pada dasarnya merupakan bagian integral dari proses pembelajaran, yang diarahkan untuk menilai kinerja peserta didik (memantau proses, kemajuan, dan perbaikan hasil belajar) secara berkesinambungan. Pelaksanaan penilaiaan dapat dilakukan secara tidak langsung pada saat peserta didik melakukan aktivitas belajar, maupun secara tidak langsung melalui bukti hasil belajar sesuai dengan kriteria kinerja (performance criteria).

Konsisten dengan pendekatan kompetensi yang digunakan, maka sistem penilaian menitikberatkan pada penilaian hasil belajar berbasis kompetensi (compepetncy based assessment) dengan ciri: menggunakan penilaian Acuan Patokan (criterion reference assesment), diberlakukan secara perseorangan (individualized). Mengacu pada kualifikasi pencapaian yang telah ditetapkan berdasarkan kurikulum UPI 2011, Keberhasilan mahasiswa ditentukan oleh seberapa jauh mata kuliah tersebut dikuasainya dan biasanya disimbolkan dengan skor yang diperoleh setelah mengikuti suatu tes atau ujian. 


\section{METODE PENELITIAN}

Metode penelitian yang digunakan dalam penelitian ini yaitu metode deskriptif komparatif. Tujuannya untuk mengetahui tingkat kompetensi dari dua kelompok responden. Penelitian yang dilakukan bertujuan untuk mengetahui perbandingan kompetensi pemesinan mahasiswa JPTM FPTK UPI yang berasal dari SMA dan SMK, dimana perbedaan kompetensi tersebut dapat dilihat dari perbedaan hasil belajar mahasiswa.

\section{HASIL PENELITIAN}

Penelitian ini dilakukan pada mahasiswa angkatan 2011 prodi produksi dan perancangan, yang terdiri dari 2 kelompok yaitu kelompok mahasiswa yang berasal dari SMA dan kelompok mahasiswa yang berasal dari SMK, masing-masing kelompok terdiri dari 5 orang. Pada Tabel 2 berikut ini ditunjukkan jumlah sampel penelitian yaitu mahasiswa JPTM UPI program S1 mata kuliah teknik pemesinan yang berasal dari SMA dan SMK.

Data pada penelitian ini merupakan hasil kemampuan mahasiswa pada praktikum teknik pemesinan. Data tersebut diperoleh berdasakan kriteria penilaian atau disebut dengan performance assesment yang biasa digunakan oleh dosen pengampu mata kuliah teknik pemesinan. Data yang telah didapatkan akan diolah dengan menggunakan statistik, sehingga didapatkan suatu kesimpulan dalam penelitian ini.

Berikut ini akan dijabarkan deskripsi hasil uji kinerja mahasiswa pada saat praktikum dengan menggunakan mesin bubut yang didapatkan dari lembar performance assesment.

Tabel 1. Hasil uji kinerja mahasiswa

\begin{tabular}{cccccccc}
\hline $\begin{array}{c}\text { Asal } \\
\text { Sekolah }\end{array}$ & Mahasiswa & $\begin{array}{c}\text { Aspek } \\
\text { Pesiapan }\end{array}$ & $\begin{array}{c}\text { Aspek } \\
\text { Sikap } \\
\text { keja }\end{array}$ & $\begin{array}{c}\text { Aspek } \\
\text { Proses kerja }\end{array}$ & $\begin{array}{c}\text { Aspek } \\
\text { Hasil kerja }\end{array}$ & $\begin{array}{c}\text { Aspek } \\
\text { Alokasi } \\
\text { waktu }\end{array}$ & $\begin{array}{c}\text { Skor } \\
\text { Total }\end{array}$ \\
\hline SMA & A & 100 & 100 & 100 & 62,5 & 100 & 85 \\
\hline & $\mathrm{B}$ & 100 & 100 & 100 & 62,5 & 100 & 85 \\
\hline & $\mathrm{C}$ & 100 & 100 & 100 & 62,5 & 100 & 85 \\
\hline D & 100 & 100 & 100 & 62,5 & 100 & 85 \\
\hline SMK & E & 100 & 100 & 100 & 50 & 100 & 80 \\
\hline & $\mathrm{F}$ & 100 & 100 & 100 & 87,5 & 100 & 95 \\
\hline $\mathrm{G}$ & 100 & 100 & 100 & 62,5 & 100 & 85 \\
\hline $\mathrm{H}$ & 100 & 100 & 100 & 62,5 & 100 & 85 \\
\hline & 100 & 100 & 100 & 62,5 & 100 & 85 \\
\hline & 100 & 100 & 100 & 50 & 100 & 80 \\
\hline
\end{tabular}


Data hasil test performance (Tabel 1) merupakan gambaran hasil kinerja seluruh mahasiswa sampel penelitian berdasarkan aspek persiapan, sikap kerja, proses kerja, hasil kerja, dan alokasi waktu. Dapat dilihat bahwa mahasiswa yang berasal dari SMA yang mendapatkan kualifikasi nilai A Sejumlah 0 (nol) orang setara dengan 0\%, kualifikasi nilai B sejumlah 5 (lima) orang setara dengan 100\%, kualifikasi nilai C 0 (nol) orang setara dengan 0\%, dan yang mendapat kualifikasi nilai D 0 (nol) orang setara dengan $0 \%$. Sementara itu mahasiswa yang berasal dari SMK yang memperoleh kualifikasi nilai A Sejumlah 1 (satu) orang setara dengan 20\%, kualifikasi nilai B sejumlah 4(empat) orang setara dengan 80\%, kualifikasi nilai C 0 (nol) orang setara dengan 0\%, dan yang mendapat kualifikasi nilai D 0 (nol) orang setara dengan $0 \%$.

Deskripsi data hasil penelitian yang telah diuraikan sebelumnya merupakan gambaran secara umum dari suatu sampel tanpa ada kesimpulan yang dapat digeneralisasikan. Selanjutnya, agar data dapat digunakan sebagai dasar pengambilan keputusan yang lebih bermakna, maka perlu dilakukan pengujian data sampel secara statistik. Adapun data yang akan diuji pada bagian ini yaitu data pencapaian kompetensi membubut rata dan bertingkat yang telah didapatkan berdasarkan masing-masing kelompok sampel. Data tersebut akan dibandingkan satu sama lain dengan melakukan uji hipotesis menggunakan uji-t.

\begin{tabular}{|c|c|c|c|c|c|c|c|c|c|}
\hline \multirow[t]{3}{*}{$U j i-t$} & SAMPEL & $\mathrm{N}$ & $\mathrm{n}-1$ & $1 / \mathrm{n}$ & SD & $\mathrm{S}^{2}$ & $(n-1) S^{2}$ & $\overline{\bar{x}}$ & $\overline{x_{1}}-\bar{x}_{2}$ \\
\hline & SMK & 5 & 4 & 0,20 & 5,48 & 30,00 & 120,00 & 86,00 & \multirow[t]{2}{*}{2,00} \\
\hline & SMA & 5 & 4 & 0,20 & 2,24 & 5,00 & 20,00 & 84,00 & \\
\hline & JMLAH & 10 & 8 & 0,40 & 7,71 & 35,00 & 140,00 & 170,00 & 2,00 \\
\hline \multicolumn{2}{|c|}{ SD Gabungan } & 4,18 & \multicolumn{7}{|c|}{ Ho di terima jika : $-\mathrm{t}_{\text {Tabel }}<\mathrm{t}_{\text {hitung }}<\mathrm{t}_{\text {Tabel }}$} \\
\hline \multicolumn{2}{|r|}{$t_{\text {hitung }}$} & 0,76 & & & & & & & \\
\hline \multicolumn{2}{|r|}{$t_{\text {Tabel }}$} & 1,86 & & & & & & & \\
\hline
\end{tabular}

Hasil perhitungan statistik (Tabel 2) dengan menggunakan uji-t yang dilakukan terhadap nilai pencapaian kompetensi membubut rata dan bertingkat antara mahasiswa yang berlatar belakang pendidikan dari SMA dan mahasiswa yang berlatar belakang pendidikan dari SMK di atas, didapatkan harga $t_{\text {hitung }}=0,76$ sedangkan harga $t_{\text {Tabel }}$ pada taraf kepercayaan $95 \%$ dan derajat kebebasan $\mathrm{dk}=8$ didapatkan harga $t_{\text {Tabel }}=1,86$.

Berdasarkan hasil tersebut, dapat dilihat bahwa $-t_{\text {Tabel }}<t_{\text {hitung }}<t_{\text {Tabel }}$, dengan demikian dapat disimpulkan bahwa tidak terdapat perbedaan yang signifikan antara hasil pencapaian 
kompetensi membubut rata dan bertingkat mahasiswa yang berlatar belakang pendidikan dari SMA dan mahasiswa yang berlatar belakang pendidikan dari SMK, dengan kata lain $H_{0}$ pada penelitian iniditerima dan $H_{l}$ pada penelitian ini ditolak.

\section{PEMBAHASAN}

Pada aspek persiapan semua mahasiswa pada sampel penelitian, baik mahasiswa yang berlatar belakang pendidikan dari SMA dan mahasiswa yang berlatar belakang pendidikan dari SMK dikategorikan baik sekali. Hal ini dikarenakan persiapan pembelajaran memang telah diterapkan waktu dimasa sekolah baik itu untukmahasiswa yang berlatar belakang pendidikan SMA maupun mahasiswa yang berlatar belakang pendidikan SMK, dengan mempersiapakan diri untuk melakukan kegiatan praktik maka hasil yang dicapai akan maksimal, termasuk didalam hal ini adalah kesiapan mental, kesiapan fisik, atau kesiapan emosi dalam melakukan suatu kegiatan atau pekerjaan.

Pada aspek sikap kerja semua mahasiswa pada sampel penelitian, baik mahasiswa yang berlatar belakang pendidikan dari SMA dan mahasiswa yang berlatar belakang pendidikan dari SMK dikategorikan baik sekali. Hal ini dikarenakan seluruh mahasiswa sampel penelitian mentaati SOP (standard operating procedure) pada aspek sikap kerja sesuai dengan ketentuan yang berlaku.

Pada aspek proses kerja semua mahasiswa pada sampel penelitian, baik mahasiswa yang berlatar belakang pendidikan dari SMA dan mahasiswa yang berlatar belakang pendidikan dari SMK dikategorikan baik sekali. Hal ini dikarenakan seluruh mahasiswa sampel penelitian dapat melakukan prosedur kerja sesuai dengan SOP yang berlaku.

Pada aspek hasil kerja, semua mahasiswa yang berlatar belakang pendidikan dari SMA dikategorikan gagal. Hal ini disebabkan minimnya pengalaman dalam praktek kerja mesin bubut mahasiswa yang berlatar belakang dari SMA sehingga rata-rata hasil kerja mahasiswa tersebut dikategorikan gagal. Sementara itu untuk mahasiswa yang berlatar belakang pendidikan dari SMK ada empat orang mahasiswa yang dikategorikan gagal dansatu orang mahasiswa termasuk dalam kategori baik. Hal ini dikarenakan sebagian besar mahasiswa tersebut masih kurang teliti dalam melakukan pekerjaan, sehingga menyebabkan hasil kerja yang kurang maksimum.

Pada aspek alokasi waktu kerja, point yang dinilai pada aspek alokasi waktu yang terdapat dalam lembar performance assesmentadalah waktu pengerjaan $\leq 120$ menit, dalam hal ini semua 
mahasiswa pada sampel penelitian, baik mahasiswa yang berlatar belakang pendidikan dari SMA maupun mahasiswa yang berlatar belakang pendidikan dari SMK dikategorikan baik sekali atau dengan kata lain seluruh mahasiswa sampel penelitian dapat menyelesaikan pekerjaan dengan tepat waktu.

Berdasarkan perhitungan uji-t yang telah dilakukan, didapatkan $t_{\text {hitung }}=0,76$. Pada taraf signifikan $5 \%$ dengan $\mathrm{dk}=8$ didapatkan $\mathrm{t}_{\text {Tabel }}=1,81 . \mathrm{H}_{0}$ pada penelitian ini diterima apabila $\mathrm{t}_{\text {Tabel }}<\mathrm{t}_{\text {hitung }}<\mathrm{t}_{\text {Tabel. }}$ Dengan demikian keputusan yang diambil adalah menolak $H_{1}$ dan menerima $H_{0}$, artinya tidak ada perbedaan yang signifikan antara mahasiswa yang berlatar belakang pendidikan dari SMA dan mahasiswa yang berlatar belakang pendidikan dari SMK.

\section{KESIMPULAN}

Pencapaian kompetensi membubut rata dan bertingkat untuk mahasiswa yang berlatar belakang pendidikan dari SMK dikategorikan baik. Hal tersebut dapat dilihat dari nilai rata-rata hasil kompetensi secara keseluruhan. Tidak terdapat perbedaan pencapaian kompetensi membubut rata dan bertingkat yang signifikan antara mahasiswa yang berlatar belakang pendidikan dari SMA maupun mahasiswa yang berlatar belakang pendidikan dari SMK.

\section{DAFTAR PUSTAKA}

Mulyasa, E. (2002). Kurikulum Berbasis Kompetensi. Bandung: Remaja Rosdakarya.

Slameto. (2003). Belajar dan Faktor-Faktor yang Mempengaruhinya. Jakarta: PT. Rineka Cipta.

Sukmadinata, N. S. (2004). Metode Penelitian Pendidikan. Bandung: Remaja Rosdakarya. Yamin, M. (2005). Strategi Pembelajaran Berbasis Kompetensi. Jakarta: GP Press. 